Universidade de Brasília

Vinícius Portella Castro

Uma ficção suprema: o caráter mítico da Constituição Federal

Brasília

2011 
Vinícius Portella Castro

\section{Uma ficção suprema: o caráter mítico da Constituição Federal}

Monografia apresentada a Faculdade de Direito da

Universidade de Brasília (UnB) como requisito à

obtenção do título de Bacharel em Direito, aprovado

com conceito SS

Brasília, (DF), 16/12/2011

Orientador: Professor Cristiano Paixão 
Vinícius Portella Castro

Uma ficção suprema: o caráter mítico da Constituição Federal

BANCA EXAMINADORA

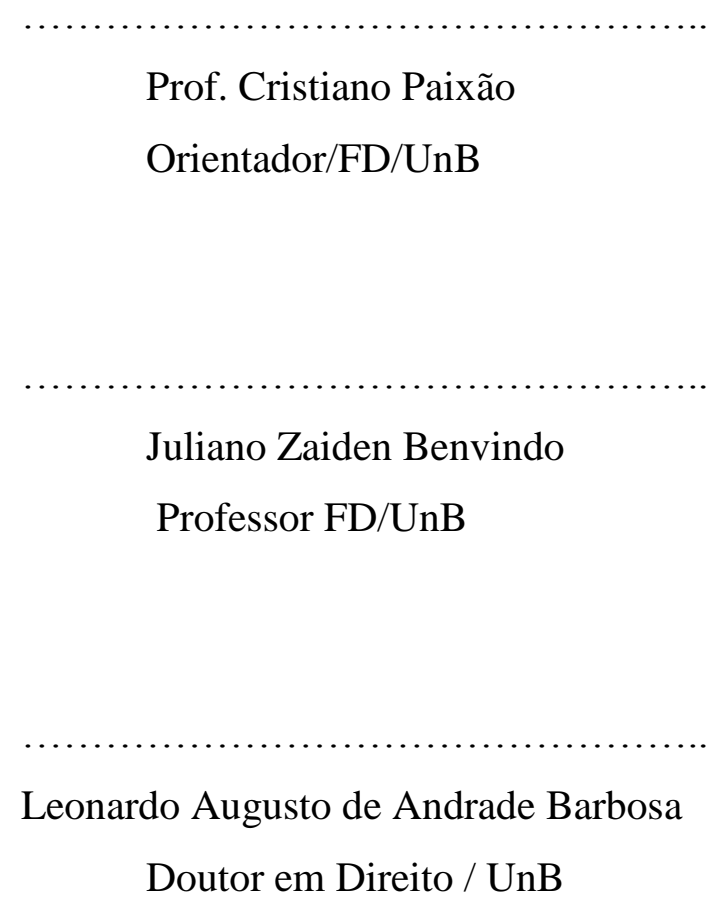


There was a Project for the sun and is

Wallace Stevens, notes toward a supreme fiction

It may perhaps seem to you as though our theories are a kind of mythology. . . But does not every science come in the end to a kind of mythology?

Freud 
RESUMO

O presente trabalho pretende investigar o caráter mítico e simbólico da Constituição

Federal de 1988, assim como de toda Constituição moderna. Serão analisados alguns dos conceitos-chave da CF, assim como alguns elementos de sua linguagem, para demonstrar os ecos e equivalências com alguns elementos e estruturas observados por pensadores modernos em suas análises sobre o mito.

Palavras-Chave: Direito Constitucional. Teoria Constitucional. Mito. Filosofia do Direito. 


\section{SUMÁRIO}

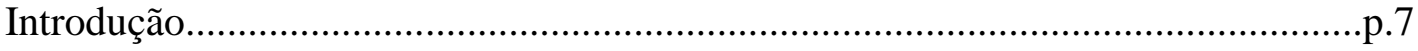

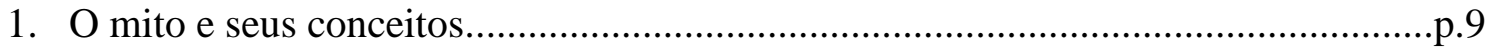

2. A Constituição como mito de origem...............................................................p.15

3. A legitimidade mítica do poder constituinte....................................................p.22

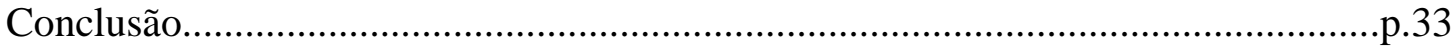

Referências Bibliográficas.........................................................................p.44 


\section{Introdução}

A Constituição é um texto. Além de ser o principal documento político e legal que orienta e legitima as realizações diárias de um Estado moderno, explicitando sua genealogia e sua posição dentro de um ordenamento racional e uma estrutura institucional, a Constituição é feita de matéria linguística e simbólica, estabelecida numa mídia expressiva específica - no nosso caso, a língua portuguesa. Essa matéria específica tem suas diversas contingências e complexidades, apesar da confiança absoluta que a linguagem de uma Constituição investe em si mesma, a confiança de que ela é não só politicamente legítima em suas pretensões, mas materialmente capaz de estabelecer com suas estruturas verbais as delimitações e os detalhamentos organizacionais de uma gigantesca estrutura institucional que vai reger a vida de milhões de pessoas por um tempo indeterminado.

Todo texto é plurívoco, dotado de diversos poderes simultâneos e forças concorrentes. A consciência da complexidade do fenômeno textual e o variegado alcance dessa complexidade é um dos principais movimentos encenados na filosofia do século $\mathrm{XX}$, realizado de maneira distinta por pensadores como Wittgenstein, Derrida, Foucault e Rorty (entre outros).

Uma das formas de compreender essa ideia da multiplicidade e da contingência histórica e antropológica por trás do texto é reconhecendo o caráter simbólico e irracional da nossa linguagem e de nossas faculdades imaginativas, identificada e analisada tantas vezes pela antropologia. As duas estruturas que parecem definir a humanidade em qualquer cultura são as estruturas linguísticas e a míticas. De fato, essa tentativa tão demarcada e rígida de separar a linguagem de seu caráter simbólico-irracional ou mítico parece ser uma característica bastante peculiar da modernidade ocidental, e talvez até exclusiva a ela.

A Constituição tem uma vivência prática extraordinária, tanto no sentido de ter seu mero conceito invocado no dia-a-dia como irradiação de legitimidade do Estado como no sentido de ter seu texto efetivamente usado como referência para a aplicação diária de preceitos e princípios normativos. Isso torna a Constituição um texto bastante distinto de outros, é claro, bastante diferente de um texto literário ou de um manual técnico. Na sua efetiva ordenação de comportamentos e instituições materialmente constituídas, a Constituição tem pouquíssimos equivalentes textuais em força e influência, superando inclusive o poder de diversos textos considerados como revelações divinas. 
Ao falar da Constituição, é claro que teremos que levar em conta não apenas um corpo de textos e conceitos estritamente jurídicos, mas também a sua vigorosa intersecção com o campo político, já que a Constituição é o maior ponto de contato entre o político e o jurídico Não há como falar seriamente de Constituição sem esbarrar nas ideias de legitimidade e representação política, por exemplo, conceitos que tem sua representação técnico-jurídica, mas que são eminentemente políticos.

A equivalência sugerida no trabalho entre a razão do estado moderno e estruturas míticas e irracionais não é nova. Nem o é exatamente a análise específica da Constituição nesse sentido (podendo chamar atenção, por exemplo, para o trabalho de Fábio Nadal ${ }^{1}$ ). Mas acreditamos que existem diversos aspectos interessantes ainda a serem abordados.

A minha análise se dará apresentando diversos conceitos modernos e contemporâneos de mito e os relacionando em seguida com elementos do texto constitucional e com construções conceituais usuais do Direito Constitucional, com a intenção de demonstrar as curiosas e expressivas equivalências possíveis entre os dois campos. Eu parto do princípio segundo o qual planos distintos de interpretação e de repercussão significativa podem conviver com o aspecto mais técnico, burocrático e estritamente jurídico da Constituição, até se misturando com ele e de certa forma reforçando a sua vigência e efetividade democrática.

\footnotetext{
${ }^{1}$ NADAL, Fábio A Constituição como mito: o mito como discurso legitimador da constituição. Método, São Paulo, 2006.
} 


\section{O Mito e seus conceitos}

\subsection{Os conceitos de mito}

Não se pode dizer que exista um conceito simples e inequívoco de mito. No senso comum, hoje em dia, mito seria alguma espécie de crença infundada, de superstição ou rumor. Essa noção do mito como basicamente uma inverdade pode ser retraçada até a oposição grega entre mythos - logos que para muitos caracteriza origem do pensamento discursivo ocidental ${ }^{2}$. Segundo corre a narrativa, mythos e logos eram a princípio termos praticamente intercambiáveis, ambos significando algo próximo de história (no sentido de relato ou narrativa) ou discurso, e a filosofia e a razão lógica como a conhecemos só teriam efetivamente nascido na Grécia a partir do momento em que se fez clara a oposição do pensamento conceitual e lógico ao pensamento e o discurso mítico (que no caso grego consistia principalmente em histórias fantásticas envolvendo entidades sobrenaturais personalizadas). O mythos seria a contraparte irracional e imagética ao discurso racional e linear de explicação do mundo que os gregos constituíam. Essa oposição direta e constitutiva ainda é bastante influente na concepção de racionalidade fundante do mundo ocidental.

Não existindo um conceito único possível de mito, o que temos são aproximações, parentescos ${ }^{3}$, como diria Wittgenstein.

Mitos são histórias sagradas, geralmente explicando a origem do cosmos ou de algum objeto cultural ou natural. De autoria anônima e importância "arquetípica ou universal"4 dentro de uma determinada cultura (o relato mítico não podendo ser simplesmente encarado como uma ficção, algo livremente constituído com fins estéticos). O mito está essencialmente ligado com o rito, a execução de atos simbolicamente revestidos que organizam e perfazem a vida religiosa e social de uma cultura. Ele se situa fora do tempo, ou num tempo escatológico, figurando deuses, semideuses e demais criaturas fantásticas, e muitas vezes estabelecendo inúmeras conexões entre

\footnotetext{
${ }^{2}$ Um relato genealógico dessa idéia pode ser encontrado em BOTTICI, Chiara. The Philosophy of Political Myth. Cambridge University Press, 1999, p.23. No entanto, a autora não concorda com essa narrativa tradicional (que ela encontra em autores importantes como Jean-Pierre Vernant, por exemplo) da oposição mythos-logos como originária do pensamento filosófico. Contrariamente, ela aponta para o uso evidente que Platão faz de imagens e relatos míticos nos seus diálogos sem jamais desqualifica-los frente as porções puramente racionais do seu discurso, e defende que para Aristóteles o pensamento mítico era uma forma válida de se tentar conhecer o mundo.

${ }^{3}$ WITTGENSTEIN, Ludwig. Investigações Filosóficas. Abril Cultural, São Paulo, 1984.

${ }^{4}$ CUPITT 1982, p.29 . Apud: COUPE, 2009, p.6
} 
um mundo sagrado ou dos mortos e o mundo cotidiano e profano. Para muitos, criar mitos seria uma função ou tendência universal da mente humana ao procurar uma visão mais ou menos unificada de ordem cósmica, de ordem social e de sentido da própria vida ${ }^{5}$.

Inúmeros pensadores já abordaram o tema, com enfoques distintos em mente, em áreas diversas de análise. Podemos encontrar maquinações conceituais sobre o mito na antropologia, na filosofia, na psicologia, nos estudos religiosos, na crítica literária e na semiologia, apenas para ficar nos mais óbvios.

No século XX, autores importantes como Ernst Cassirer, Mircea Eliade, Freud, Jung, Roland Barthes e Lévi-Strauss se debruçaram detidamente sobre o seu poder e sua relevância em diversos âmbitos das ciências humanas, com resultados e objetivos distintos.

Naturalmente, todos esses esforços teóricos tem campos distintos de efetividade e relevância, muitas vezes parecem até tratar de fenômenos distintos. Mas entendemos que existe um substrato básico na análise moderna do fenômeno mítico, e que abordando rapidamente algumas de suas diversas manifestações nós teremos uma possibilidade mais fecunda de estudar suas conexões com a linguagem jurídica e constitucional. Dessa forma dispomos de mais enfoques e filtros discursivos. Não estamos estabelecendo uma teoria única do mito para então fixar uma relação estanque e absoluta entre ela e o texto constitucional. Estamos procurando equivalências sutis entre sugestões distintas de significado mítico e a Constituição, e por isso o uso pontual de autores diferentes parece metodologicamente adequado.

\subsection{Brevíssima história do mito.}

Apesar da oposição mythos-logos estar presente na tradição filosófica desde os gregos, só podemos efetivamente dizer que o estudo do mito como abstração efetivamente começou com a modernidade, notavelmente na avalanche de estudos sobre o homem e a sociedade que marcaram o início da sociologia e dos estudos etnográficos.

Um curioso antecedente muitas vezes deixado de fora das histórias sobre o conceito de mito seria Giambattista Vico, o original pensador italiano nascido no século dezessete. Ele

\footnotetext{
${ }^{5}$ CUPITT 1982, p.29 . Apud: COUPE, 2009, p.6
} 
sugere no seu Principi di Scienza Nuova d'intorno alla Comune Natura delle Nazion ${ }^{6}$ uma conexão interessantíssima entre o mito e o nascimento da faculdade linguística no homem, entendendo que imaginação mítica possui uma lógica poética de projeção antropomórfica de explicação do mundo ${ }^{7}$, uma espécie de animismo (como denominaria Tylor séculos depois) responsável pela denominação simbólica da natureza que o homem realiza em toda cultura.

Para Andrew Von Hendy ${ }^{8}$, o conceito de mito efetivamente é uma invenção moderna, começando com as formulações de poetas e filósofos ingleses e alemães relacionados ao romantismo. Poetas como Schelling, Schlegel e Wordsworth encontraram nas figuras expressivas e míticas das tradições clássicas e orais algo como um "veículo de transcendência" para a literatura moderna na sua luta estética entre crença e descrença 9 .

Hemdy traça um sinuoso caminho para a construção moderna do mito, que teria se infiltrado no aparato conceitual construído por Marx sobre 'ideologia', se fortalecido com Thomas Carlyle na forma de uma história envolvendo heróis que ajuda a construir uma cultura, ganhado ímpeto em Nietzsche às vezes como uma "mentira socialmente construída" que devemos destruir, às vezes como uma poderosa (ainda que falsa) forma de potencializar a dimensão estética do mundo ${ }^{10}$ e desaguado no século XX de maneira bastante forte com o progresso dos estudos antropológicos da época.

$\mathrm{Na}$ antropologia, inicialmente, o mito aparece como uma forma de narrativa que os povos primitivos consideravam sagrada. As análises de Levi-Bruhl e Frazer ${ }^{11}$ contribuíram para uma semelhante ideia do mito como um estágio primitivo da inteligência humana, basicamente uma maneira inferior de explicação causal do mundo plenamente superada numa escada evolutiva linear pelo pensamento racional e científico.

No pensamento de Freud ${ }^{12}$ e Jung e na literatura modernista de James Joyce e T.S. Eliot podemos perceber a disseminação variada da ideia de que os mitos não são apenas contos folclóricos primitivos e curiosos de interesse histórico, estados rudimentares e inteiramente superados de pensamento presentes apenas em povos primitivos, mas sim estruturas simbólicas

\footnotetext{
${ }^{6}$ VICO, Giambattista. Princípios de uma ciência nova acerca da natureza comum das nações: (acerca da natureza comum das nações). São Paulo: Abril Cultural, 1973. 185 p.

${ }^{7}$ BURKE, Peter. Vico. São Paulo, Editora UNESP, 1997

${ }^{8}$ VON HEMDY, Andrew, The modern construction of myth, Indiana University Press, 2001

${ }^{9}$ VON HEMDY, op cit., p.49

${ }^{10}$ VON HEMDY, op cit., p. 75.

${ }^{11}$ Embora Frazer use mais os conceitos de 'rito', 'magia' e 'religião', boa parte de sua análise pode ser facilmente transferida para o estudo dos mitos. FRAZER, James. The Golden Bough. Wordsworth Editions, Kent, 1993.

${ }^{12}$ FREUD, Sigmund. Totem e tabu. Rio de Janeiro: Imago, 2005.
} 
que ainda detem uma influência considerável nas nossas forças imaginativas, na maneira que figuramos o mundo. Acontece, em certa medida, um retorno à influência recebida dos mitos no romantismo, mas agora melhor fundamentado com os avanços dos relatos e dos estudos etnográficos.

Lévi-Strauss ${ }^{13}$ realiza um estudo estruturalista do mito, preocupado, entre outras coisas, em explicar a gramática elementar dos procedimentos de significado dos mitos, que para ele subsiste intocada apesar da extrema variabilidade das narrativas (tradicionalmente orais). LéviStrauss não só acredita que existe um ordenamento básico e aparentemente universal na capacidade humana de criar mitos, mas chega a dizer no seu livro Pensée Sauvage ${ }^{14}$ que a lógica seguida pelo pensamento mítico seria tão rígida quando a do pensamento científico moderno.

Essa espécie de perspectiva que se preocupa em relativizar ou até mesmo negar a progressão linear e perfeitamente objetiva do pensamento mítico até o racional-científico (consequentemente relativizando também a famosa oposição mythos-logos supostamente encenada na antiguidade) é predominante na segunda parte do século XX e nos autores de que nos serviremos de forma mais detida.

\subsection{Validade da análise mitográfica da Constituição}

Uma análise mitográfica da Constituição precisa obviamente se justificar, não constando nem o estudo dos mitos no arsenal teórico usual das ciências jurídicas e nem os documentos jurídicos como objetos naturais de análise dos mitógrafos. Primeiro é preciso deixar claro que o meu foco é no conceito mais técnico de mito, aquele apanhado da antropologia e da filosofia (de uma narrativa tradicional profundamente relacionada a determinados objetos e elementos de uma cultura), e não no sentido mais simples presente na linguagem comum: de uma inverdade ou de uma representação ideológica coletiva. Não queremos desmistificar a Constituição, apontá-la como uma construção ideológica falaciosa.

A pretensão é a de apontar que a Constituição pode ter aspectos míticos e simbólicos profundamente enleados na sua linguagem (e, portanto, na sua matéria política e jurídica). Isso não seria uma negação da efetividade institucional e política da Constituição e nem mesmo exatamente uma refutação de sua coerência estrutural e racional.

${ }^{13}$ LÉVI-STRAUSS, Claude., Antropologia Estrutural, Tempo Brasileiro, Rio de Janeiro, 1985.

${ }^{14}$ LÉVI-STRAUSS, Claude,. Pensée sauvage. Paris: Plon 
A minha intenção ao chamar atenção para os aspectos simbólicos e míticos da Constituição não deve ser de uma suposta purificação cientificista, como se pretendêssemos depurar a ciência jurídica de impurezas e imprecisões irracionais, ou talvez denunciar uma hipertrofia simbólica da Constituição em detrimento de sua efetividade prática ${ }^{15}$.

Longe disso. Esse trabalho tentará estabelecer de que forma esses aspectos míticos destacados da linguagem da Constituição podem ser encontrados em diversas outras culturas e diversas outras manifestações da imaginação humana. Kenneth Burke já disse que o homem é o "symbol-using animal", ou o animal simbólico, já que aquilo que chamamos de realidade foi inteiramente construído a partir de nosso sistema simbólico ${ }^{16}$. Tendemos a concordar com Burke, e acreditar que estes são traços da nossa imaginação que devemos compreender da melhor forma possível, e não simplesmente rechaçar.

Como já explicamos, se há uma característica dominante no estudo dos mitos na segunda metade do século XX em diante é a compreensão de que ainda somos profundamente definidos e estruturados por eles, que eles ainda se encontram presentes na nossa linguagem e nos nossos aparatos conceituais ${ }^{17}$. Embora o termo ainda seja principalmente usado para significar uma inverdade ou representação inválida ou ingênua, muitos são os pensadores que defendem a validade do mito enquanto forma de expressividade ou até de pensamento conceitual.

Paul Ricoeur, por exemplo, argumenta que devemos ir além da visão moderna do mito como uma explicação falsa até uma noção de sua significação exploratória e sua contribuição para o entendimento, falando também da sua função simbólica e do seu poder de descoberta e revelação ${ }^{18}$.

Da mesma forma, Blumenberg propõe que conteúdos mitológicos podem ser sempre revitalizados e reinterpretados:

Loin de leur origine et de leur fonction authentique, des contenus mythologiques peuvent être encore et toujours repris et interpretés, variés et accentués différemment, pour servir de figures

\footnotetext{
${ }^{15}$ Como em: Neves, Marcelo. A Constitucionalização Simbólica. Martins Fontes. São Paulo, 2011.

${ }^{16}$ BURKE, Kenneth. Language as symbolic action. Berkeley: Univ California Press, 1968

${ }^{17}$ KOLAKOWSKI, Presence of Myth Chicago: University of Chicago Press, 2005.

18 “'(...)we must go beyond the modern view of myth as 'false explanation' to a sense of its 'exploratory significance and its contribution to understanding'. He speaks of the 'symbolic function' of myth, its power of discovery and revelation. (COUPE, Lawrence. Myth, Routledge, 2009, London, p.8 )
} 
directrices em vue de déterminer de manière élémentaire notre conception de nous-mêmes et du monde. (BLUMENBERG,2005.p.12)

Roland Barthes no seu livro Mythologies propõe um conceito bastante particular de mito, mais focado no seu caráter formal dentro de um sistema semiológico, ou seja, de sua estrutura de comunicação:

"le mythe est un système de communication, c'est un message. On voit par là que le mythe ne saurait être un objet, un concept, ou une idée; c'est un mode de signification, c'est un forme." (BARTHES, 1957, p.182)

O seu livro realiza um movimento de interpretar diversos elementos da sociedade moderna como mitos nesse sentido formal de uma mensagem. Nesta concepção, tudo poderia ser um mito, já que o universo é infinitamente sugestivo ${ }^{19}$.

Para Barthes a mitificação de um objeto discursivo seria a naturalização de algum de seus significados $^{20}$. Não parece absurdo apontar que a análise de Barthes é mais próxima de um conceito de ideologia do que propriamente de um estudo sobre mitologia ${ }^{21}$. Barthes não tenta aproximar o seu conceito de qualquer relação com o sagrado, com rituais, com narrativas fundamentais ou com qualquer outra forma de absoluto que justificasse plenamente o uso que ele faz da palavra 'mito'. De qualquer forma, não deixa de ser uma análise extremamente interessante das diferentes formas de significação contidas em qualquer forma simbólica (o que obviamente inclui a Constituição) e principalmente da maneira dessas formas de significação serem naturalizadas dentro de determinados procedimentos discursivos.

Embora a minha análise não partilhe exatamente desse conceito formalista de um mito como um sistema de comunicação, pura e simplesmente, podemos reportar a ele um ímpeto semelhante de analisar objetos discursivos atrás de reverberações distintas daquelas oficiais e imediatamente disponíveis.

\footnotetext{
${ }^{19}$ BARTHES, 1957, p.182

20، Nous sommes ici au principe même du mythe; il transforme l'histoire en nature”. BARTHES, 1957, p.202)

${ }^{21}$ De fato muitos já fizeram essa constatação, por exemplo: VOM HENDY, 2001, p.290.
} 


\section{A Constituição como Mito de Origem 2.1 Constituição e tempo mítico}

O romeno Mircea Eliade, um dos pensadores mais influentes a respeito do mito no século $\mathrm{XX}$, apresenta uma visão do mito que nos será bastante útil, centrada principalmente na ideia do mito de origem.

"le mythe raconte une histoire sacrée; il relate un événement qui a eu lieu dans le temps primordial, le temps fabuleux des "commencements". Autrement dit, le mythe raconte comment, grâce aux exploits des Etres Surnaturels, une réalité est venue à l'existence, que ce soit la realité totale, le Cosmos, ou seulement un fragment: une île, une espèce végétale, un comportement human, une institution. C'est donc toujours le récit d'une "création": on rapporte comment quelque chose a été produit, a commencé à être. "(ELIADE, 2007, p.17)

Ou seja, o mito seria sempre a história de uma criação, algo como uma explicação narrativa para a origem de algum fenômeno. $\mathrm{O}$ mito que explica a origem de alguma coisa se chama mito etiológico (etiologia é o estudo das causas).

Isto se relaciona com a análise estrutural que Lévi-Strauss faz do mito:

Um mito diz respeito, sempre, a acontecimentos passados: "antes da criação do mundo”, ou "durante os primeiros tempos", em todo caso, "faz muito tempo”. Mas o valor intrínseco atribuído ao mito provém de que estes acontecimentos, que decorrem supostamente em um momento do tempo, formam também uma estrutura permanente. Esta se relaciona simultaneamente ao passado, ao presente e ao futuro. (...) Nada se assemelha mais ao pensamento mítico que a ideologia política ${ }^{22}$. Em nossas sociedades contemporâneas, talvez testa tenha se limitado a substituir aquele. (LÉVI-STRAUSS, 1985, p. 241)

O que ressoa aqui com particular força é essa definição do mito como uma narrativa ou estrutura de significado que decorre tanto antes do tempo como no presente e no futuro. Como no caso de Eliade, algo situado há muito tempo atrás que ainda deve ecoar no presente. A equivalência com a mera ideia de um texto legislativo me parece imediata, e particularmente

\footnotetext{
${ }^{22}$ Levi Strauss já faz parte do meu trabalho aqui, ao relacionar o pensamento mítico à ideologia política. De fato, ele está longe de ser o único pensador a fazer essa relação (Ver por exemplo: CASSIRER, Ernst. The Myth of The State, Yale University Press, 1946)
} 
com a Constituição . Todo texto legislativo precisa se situar ao mesmo tempo com o presente e o futuro, numa relação tensa de prefiguração.

Direito e Estado, de qualquer forma que os entendamos, são ordenamentos, ou seja, representações da ordem que se sempre se referem ao passado. São sedimentações de condensados de sentido ou suas negações. (...) Direito e Estado, contudo, são também esquematizações, delineamentos, esboços do futuro. Ou melhor, em suas representações há uma representação do futuro. ${ }^{23}$

A Constituição, em particular, tem sempre suas circunstâncias históricas bastante delimitadas, mas sempre aspira no seu texto a uma condição externa, superior à contingência de um mero processo legislativo trivial. Seus lineamentos legislativos precisam ser ao mesmo tempo legais e supralegais, já que eles tem por definição a propriedade supostamente definitiva de vinculação, a impossibilidade de serem debatidos ou revertidos enquanto na vigência daquele mesmo sistema. Uma situação que Corsi define como: "No presente decide-se sobre uma constituição que deverá valer no futuro como um passado vinculante, mas apenas até que em um presente futuro não se decida por modifica-la,"24

Ela precisa se situar como que fora do âmbito legislativo tradicional para solucionar com uma dimensão política aquele que Luhmann chama de "o problema de auto-referência do sistema jurídico".

Para ele, efetivamente, a Constituição seria o acoplamento estrutural entre dois sistemas sociais autônomos, a política e o direito, na medida em que ela "possibilita uma solução jurídica do problema de autorreferência do sistema político e, ao mesmo tempo, uma solução política do problema de autorreferência do sistema jurídico."(LUHMANN, 1990, p.202, apud NEVES, 2011, P.66

Ao mesmo tempo que ela parece querer se libertar das amarras da contingência história, fixando um determinado momento político como absolutamente legítimo para organizar um ordenamento jurídico, ela fixa num eterno presente verbal as delimitações políticas futuras de uma população específica. Isso nos remente ao caráter específico do tempo mítico destacado por

\footnotetext{
${ }^{23}$ DE GIORGI, Rafaelle. "Estado e Direito no fim do século." In: p.;37,37. Apud: Paixão, 2002, p. 270.

${ }^{24}$ CORSI, Giancarlo. Sociologia da Constituição. Trad. Juliana N. Magalhães. Revista da Faculdade de Direito da Universidade Federal de Minas Gerais. №39. Belo Horizonte: UFMG, janeiro-junho de 2001.
} 
Lévi-Strauss, "sua dupla natureza, ao mesmo tempo reversivel e irreversível, sincrônica e diacrônica." (LÉVI-STRAUSS, 1985, p.243)

Uma narrativa mítica é contada como se tivesse ocorrido fora do tempo, e seus eventos fixos parecem definir indefinidamente o funcionamento de alguma estrutura do mundo natural. Como aponta o brasileiro Viveiros de Castro, discípulo de Levi-Strauss:

Assim, o mito não é apenas o repositório de eventos originários que se perderam na aurora dos tempos; ele orienta e justifica constantemente o presente. (...) $O$ mundo perfeito do mito se declina, por assim dizer, no pretérito imperfeito, ou em uma espécie de aoristo ${ }^{25}$. (...) O mito existe como referência temporal, mas, acima de tudo, conceitual. (VIVEIROS DE CASTRO, 2011, p.69)

Essa compreensão do mito como uma referência conceitual nos lembra as diversas vezes em que Levi Strauss sugere que o mito, apesar de sua aparente ilogicidade, cumpre o papel do pensamento conceitual ${ }^{26}$.

Para compreender melhor esta complicada e sugestiva relação, devemos nos debruçar de maneira mais detida na relação do direito e da modernidade com o tempo. Nas sociedades arcaicas e antigas podemos dizer que existe um sistema mítico ligando solidamente o passado ao presente de forma a abolir suas diferenças e elidir a temporalidade. ${ }^{27}$ Já nas sociedades modernas e hipercomplexas existe, para Luhmann, "uma superprodução de possibilidades que só podem ser parcialmente realizadas" (LUHMANN, Sociologia do Direito I. p.255, In: PAIXÃO, 2002, p.250), o que cria a formulação de um "futuro em aberto" como fator decisivo para a "diferenciação funcional do direito da sociedade moderna"( PAIXÃO, 2002, p. 250) . Isto traz a dimensão do futuro em aberto como a principal dimensão temporal do tempo moderno. A

\footnotetext{
${ }^{25}$ Tempo verbal de algumas línguas indoeuropéias como o grego e o sânscrito que pode ser definido como um tempo passado indefinido ou indeterminado.

26 "Talvez descobriremos um dia que a mesma lógica se produz no pensamento mítico e no pensamento científico, e que o homem pensou sempre do mesmo modo. O progresso - se é que então se possa aplica o termo - não teria tido a consciência por palco, mas o mundo, onde uma humanidade dotada de faculdades constantes ter-se-ia encontrado, no decorrer de sua longa história, continuamente às voltas com novos objetos." (LÉVI-STRAUSS, 1985, p. 265) A mesma ideia também está presente em Myth and Meaning, Routledge, Digital Edition. Esta ideia já estava presente em antropologos anteriores a LéviOStrauss como Lévi-Bruhl e James Frazer, com a diferença que estes dois últimos colocavam o pensamento mítico como a base de uma pirâmide evolutiva clara e inequívoca que culminaria no pensamento científico, algo contrário ao que mantinha Lévi-Strauss disposto a ter o pensamento mítico e o científico como igualmente válidos, ainda que um deles fosse obviamente mais sucedido nas esfera prática.

${ }^{27}$ PAIXÃO, 2002, p.244.
} 
vigência e constância do direito não se baseiam mais apenas numa invariância baseada no passado, ela agora é "interpretada tendo em vista o futuro". ${ }^{28}$

Mas é evidente que o futuro em aberto do direito da sociedade moderna definida por sua extrema complexidade e contingência também precisa manter uma forte relação com o passado para se constituir plenamente. Segundo Paixão, o direito teria então uma dúplice função na dimensão temporal: tanto a de estabilizar as expectativas da sociedade de forma contrafática, estabelecendo uma continuidade entre o passado e o presente, quanto a de servir como guia de comportamentos para a possibilidade de mudança e de direcionamento ao futuro ${ }^{29}$.

Em nenhuma outra estrutura normativa essa característica temporal ambígua do direito moderno se encontra realizada de maneira mais exemplar do que na Constituição. A Constituição precisa ser essa negociação entre a permanência e a fluidez, precisa manter seu núcleo estrutural democrático e ainda permitir espaço tanto para a possibilidade de sua própria reforma jurídica quanto para diversas outras instâncias de abertura democrática.

Essa dúplice função da Constituição não é exatamente paradoxal, mas tampouco é plenamente harmônica. É claro que tratamos de funções um tanto opostas ao falar da necessidade de permanência quase absoluta e da necessidade de abertura democrática para o futuro. Da mesma forma que a outra tensão definidora da Constituição: o fato dela ser o ponto de encontro do político e do jurídico, tensão que precisa ser reconciliada, ou redimida, de alguma maneira. Eu proponho que uma das formas dessas duas tensões serem reconciliadas ${ }^{30}$ é a carga mítica de sua linguagem, o tempo mítico que ela institui como síntese da permanência e da fluidez constitucional e a enunciação mítica em que ela se constitui como síntese do seu caráter político de legitimação e do seu caráter jurídico de positivação.

Com isso, não quero dizer que a Constituição efetivamente nos retorna a um tempo mítico e a uma relação com o tempo idêntica a que tinha alguns povos arcaicos. Como já foi dito, de fato a dimensão temporal da modernidade mantém uma relação com o futuro e com a história que não pode ser de maneira nenhuma confundida de maneira trivial com a ideia de tempo dominante em outros momentos históricos. Mas justamente num aspecto específico da dimensão temporal do direito moderno: a sua necessária ambiguidade entre a continuidade do passado e a

\footnotetext{
${ }^{28}$ LUHMANN, Sociologia do Direito II.Apud: Paixão, 2002, p.253.

${ }^{29}$ PAIXÃO, 2002, p. 270

${ }^{30}$ A sugestão de que o mito seria uma forma de reconciliação de contradições ou de opostos pode ser encontrada tanto em LÉVI-STRAUSS, 1985, p. 265, quanto em GRAS, Vernon W. Myth and the Reconciliation of Opposites: Jung and Levi-Strauss. Journal of the History of Ideas ,Volume 42, Issue 3, 1981. p.471-488.
} 
abertura para o futuro, acreditamos que opera uma carga simbólico-mítica da linguagem constitucional. Não de forma a repetir integralmente uma relação arcaica com o tempo, mas de forma a possibilitar a efetividade simbólica de uma linguagem constitucional sobrecarregada de diversas funções, algumas delas contraditórias.

Mas se a Constituição de fato funcionar em parte como um mito, se o tempo de sua "narrativa" é um tempo mítico, o que é que ela está fundando, que história é essa que ela relata?

\subsection{Constituição como Mito de Origem}

O antropólogo Bronislaw Malinowski ao apresentar sua própria concepção de mito estabelece uma conexão fortíssima entre o mito e suas circunstâncias práticas, seu contexto e função social, o jeito com que ele é contado e a maneira de ser recebido pelos membros de uma cultura $^{31}$. Ele não acredita exatamente na suposta vontade de explicar o presente no homem primitivo, por isso não usa o termo ‘etiológico'. Prefere explicá-lo como uma realidade viva, não uma explicação intelectual ou uma imagem artística, mas uma carta de direitos pragmática e sociológica de fé e sabedoria moral ${ }^{32}$. Para ele importam efetivamente as funções sociológicas satisfeitas pelo mito, funções relacionadas à natureza da tradição, à continuidade da cultura e a atitude humana em relação ao passado ${ }^{33}$. Para ele, os mitos são muitas vezes ajustados $a d$ hoc para lidar com situações cambiantes de direitos territoriais e divisões sociais. Isso confronta, de certa forma, uma noção tradicional dos mitos como estruturas fixas de explicação do mundo. Ele chega a dizer sobre um mito de origem de uma cultura específica que ele seria o charter legal de uma comunidade.

Resumidamente:

The function of myth, briefly, is to strengthen tradition and endow it with a greater value and prestige by tracing back to a higher, better, more supernatural reality of initial events. ${ }^{34}$

Malinowski tampouco compreende sua análise restrita a povos de culturas mais simples e homogêneas. Para ele esse tipo de mito de função sociológica é ingrediente de toda cultura, e toda mudança histórica criaria sua própria mitologia ${ }^{35}$.

\footnotetext{
${ }^{31}$ MALINOWSKI, Bronislaw. Magic, science, and religion: and other essays. London: Condor, 1974. p.105 ${ }^{32}$ MALINOSKI,1974, p.101

${ }^{33}$ MALINOWSKI. 1974, P.146

${ }^{34}$ MALINOWSKI, 1974, p.146
} 
Não é difícil extrair dessa ideia um paralelo com a Constituição, uma ideia do texto constitucional como uma espécie de 'charter' sociológico e legal de um determinado povo.

Além dessa equivalência com o 'charter' cultural de Malinowski, existem outras maneiras de se compreender a Constituição como mito fundador de uma cultura, muitas delas envolvendo a noção de que um mito fundador é um mito etiológico, ou mito de origem (algo que Malinowski não aceitava, como já foi dito)

Podemos compreender a Constituição como um mito etiológico de origem de duas maneiras diferentes, realizando duas etiologias distintas. A primeira delas seria como a origem não só do Estado ${ }^{36}$ como um todo, de todo o poder político institucional, mas também da nação coletivamente compreendida. É bom lembrar que diversos autores reportam à Constituição essa função primordial de unidade e integridade tanto para a ordem legal quanto para a sociedade como um todo, ajudando a determinar valores não estritamente jurídicos.

Em nenhuma outra cultura constitucional isto é mais claro do que nos Estados Unidos, onde a independência e a criação do país e do povo estão essencialmente conectadas ao estabelecimento da sua Constituição, com seus nobres pais fundadores e as circunstâncias quase épicas de sua confecção.

No Brasil temos uma Constituição de recém-completados vinte anos, e antes dela não podemos tiver que tenhamos tido uma Constituição de real vigor simbólico a ponto de se confundir com a fundação do país e de um povo. Aparentemente, o que temos no Brasil poderia ser chamado de uma série de narrativas históricas que se substituem com a vigência de um novo modelo, com a atual Constituição de 1988 funcionando de maneira próxima a de um mito de fertilidade, no caso uma repetição dos motivos encontrados nos mitos relacionados à primavera $^{37}$, uma revitalização democrática depois de mais de vinte anos de exceção e de uma terra constitucional e democraticamente devastada ${ }^{38}$.

Nessa ótica, o poder constituinte de 1988 seria considerado um momento político privilegiado de restauração da 'fertilidade' democrática de um povo. Essa tendência de se valorizar a possibilidade de renovação da Constituição Federal é evidente em diversos documentos da época, inclusive nos mais críticos:

\footnotetext{
${ }^{35}$ MALINOWSKI, 1974, p.146

36 "La constitucion no solo es noma, sino tambien realidad integradora do Estado"

GARCÍA-PELAYO, Manuel. Derecho Constitucional Comparado. Alianza Editorial, Madrid, 2000. p. 85

${ }^{37}$ FRYE, Northrop. The Anatomy of Criticism. Princeton University Press, Princeton, 1957.

${ }^{38}$ Esse motivo mítico é encenado de forma ostensiva nas denominações "Primavera de Praga" e "Primavera Árabe".
} 
Mesmo aqueles que enxergavam o poder Constituinte com ambivalência crítica parecem enxergar no processo Constituinte e no momento subitamente instalado no país um momento decisivo de reconstituição institucional e de construção democrática, de acordo com suas particularidades políticas e específicos anseios de legitimidade. Mesmo quem critica a compreensão do Poder Constituinte como um ato mítico fundador do Estado defende com veemência a importância da reativação permanente desse Poder através das instituições sociais e políticas do país. ${ }^{39}$

Mas também podemos compreender a Constituição como apenas o mito de origem da ordem jurídica, a narrativa que explica a origem e contribui com a eficácia simbólica ou legitimação democrática de um sistema de normas cogentes hierárquicas. Neste sentido a equivalência também me parece correta.

No próximo capítulo, detalharei um pouco melhor de que forma funciona a relação entre a enunciação mítica da Constituição e a sua legitimação democrática.

${ }^{39}$ FORTES, Luíz Roberto Salinas; NASCIMENTO, Milton Meira. A constituinte em debate: Colóquio realizado de 12 a 16/05/86, por iniciativa do Depto. de Filosofia da USP. São Paulo: Sofia, 1987p.228 


\section{A legitimidade mítica do poder Constituinte}

\subsection{Constituição e Legitimidade}

O fenômeno da Constituição é anterior ao Estado moderno e não se limita a ele. No entanto, para os efeitos deste estudo, nos limitaremos a comentar as propriedades da Constituição moderna, exemplificada historicamente por excelência pela Constituição dos Estados Unidos, hoje tomada como o paradigma pretensamente universal e quase absoluto de legitimação e estruturação de um Estado democrático de direito tendo como base a noção liberal de autolimitação do poder público perante o indivíduo.

Mais especificamente, a minha preocupação será principalmente a Constituição brasileira de 1988, que parte claramente desse paradigma político sem deixar de ter suas particularidades (notavelmente o seu caráter aberto e utópico).

Sabemos de que forma se deu e ainda se dá se essa construção teórica historicamente. Principalmente a partir das Revoluções Francesas e Americana, o mundo ocidental passa a recorrer ao poder popular como fonte de legitimação mais direta do poder. Como aponta Canotilho:

“o domínio politico (...) precisa de legitimação; a legitimação do domínio político só pode derivar do próprio povo e não de qualquer instância <<fora〉> do povo real (ordem divina, ordem natural, ordem hereditária, ordem democrática)" (CANOTILHO, 1997, p.281)

Esta necessidade de legitimação do poder se firma junto com o amadurecimento de uma série de instituições e princípios democráticos e com as sucessivas ondas de reinvindicação por direitos fundamentais, de forma que a legitimidade de um estado democrático de direito não mais se firma pela mera delegação de vontades a representantes eleitos e o cumprimento de uma estrutura formal de legalidade. Agora se fala de uma representação democrática material, de uma legitimidade que "assenta também nos conteúdos dos atos do órgão representativo". 40

A Constituição é o principal instrumento jurídico e político para a efetivação desse Estado democrático de direito. Ela ao mesmo tempo funda, limita, orienta e legitima o poder político. Ela faz isso através de uma representação democrática cristalizada e da garantia de

\footnotetext{
${ }^{40}$ CANOTILHO, 1997, p. 283
} 
determinados procedimentos legais e direitos fundamentais que efetivamente tornem a sua representatividade democrática material, e não apenas formal, fruto de uma delegação simbólica. Como aponta Canotilho:

A constituição confere legitimidade a uma ordem política e dá legitimação aos respectivos titulares do poder político. Precisamente por isso se diz que a constituição se assume como estatuto jurídico do político (Castanheira Neves) num duplo sentido - o da legitimidade e da legitimação (CANOTILHO, 1997, p.1275)

Mas como se opera essa legitimação? De que forma podemos dizer de maneira tão definitiva que um determinado modelo político fixado por determinados representantes num determinado momento histórico tem legitimidade para ordenar a vida das pessoas por um período indeterminado de tempo? Porque que a legitimação cristalizada pela Constituição não pode ser contestada?

Parece-me necessário deixar claro que não estou aqui de fato contestando a efetividade política ou a validade das laboriosas construções teóricas por trás do Constitucionalismo do estado moderno de direito. É evidente que as construções mais sofisticadas da legitimação do poder anteveem com alguma distância essas críticas sugeridas aqui, e as incluem nas suas argumentações. Habermas, por exemplo, responsável por algumas das construções teóricas mais sofisticadas a respeito das possibilidades constitutivas e legitimadoras da razão democrática, reconhece com extrema sutileza a dificuldade de se estabelecer no debate político contemporâneo pretensões de validade redimíveis discursivamente. “'Significação' é um escasso recurso e está se tornando ainda mais escasso" (HABERMAS, 2002, p.96), ele diz, no sentido de que no mundo dessacralizado contemporâneo destituído das ordens naturais e divinas de legitimação se torna bastante difícil estabelecer valores que não sejam desmontáveis e passíveis de deslegitimação. Toda doutrina política parece vulnerável às infinitas linhas de pensamento crítico.

Para Habermas, é possível compreender uma intersubjetividade política mediada pelo uso da linguagem, uma prática comunitária discursiva que não se pauta meramente pelas exigências de uma consistência formal e lógica, mas busca uma conduta processual de argumentação e justificação públicas que culminem em formas provisórias de consensualidade. Nesse sentido, a Constituição não pode ser cegamente aceita como um momento fundador do direito positivo (ou 
um ato místico inquestionável de um poder fundante de uma ordem jurídica), precisando existir uma validação crítica proveniente desse agir comunicacional ${ }^{41}$.

Tanto Habermas quanto Weber compreendem a legitimação do poder por um prisma racional. Weber entende que a dominação legal adquire caráter racional porque ela "não se confunde simplesmente com a fé na tradição ou no carisma, uma vez que ela tem a ver com a racionalidade que habita na forma do direito e que legitima o poder exercido nas formas legais" (HABERMAS, 2003, 193)

Já para Habermas, a legalidade só produz legitimidade quando a ordem jurídica reage à necessidade de fundamentação de sua positividade e institui processos de decisão jurídica que sejam permeáveis a discursos morais ${ }^{42}$. E para ele a única forma de se imaginar uma democracia material legítima é a partir de um paradigma procedimental, uma formulação das condições necessárias para que o povo possa "descobrir seus problemas e o modo de solucioná-los" (HABERMAS, 2003, p. 189). A viabilidade desse projeto se baseia numa crença fundamental nas possibilidades democráticas de práticas de autodeterminação comunicativa, uma crença na racionalidade compreendida através da intersubjetividade e da mediação discursiva.

Lembrando a compreensão de Luhmann da Constituição como um acoplamento estrutural entre os sistemas jurídico e político e como a solução para os problemas de autorreferência sofridos pelos dois sistemas, podemos fundamentalmente descrever o sentido desse acoplamento e dessa solução de autorreferência como uma resposta ao problema de legitimação.

Como aponta Soler, todo sistema jurídico tem a necessidade de limitar o retrocesso fundante:

A limitação do retrocesso fundante, além de ser um aspecto formal de toda estrutura jurídica, é concretamente uma característica positiva de todo sistema vigente de direito. A coisa julgada insere-se nessa estrutura fechada. Não recebe sua validez de nenhum sopro carismático que lhe infunde o órgão do Estado; é que todo sistema jurídico autolimita não apenas o retrocesso fundante no sentido expresso acima, mas também o processo dedutivo, estabelecendo também aqui um limite além do qual não pode ir." (SOLER, Sebastián. La interpretacion de la Ley, Barcelona: Ariel, 1962,p.95-96 (Apud MENDES, 2007, p.3)

\footnotetext{
${ }^{41}$ GOYARD-FABRE, Simone, 1999, p.483

${ }^{42}$ HABERMAS, 2003, p. 216
} 
Ou seja, a Constituição moderna pode ser compreendida, entre outras coisas, como a grande solução encontrada para o problema da legitimação do poder público e a realização de uma forma materialmente democrática e estável (que não permita questionamentos e incertezas dentro da sua própria estrutura vigente).

Sem prejuízo específico da validade teórica de nenhuma dessas valorosas explicações, podemos ainda tentar compreender este fenômeno da legitimação operada pelo texto Constitucional em seus aspectos simbólicos e míticos. Nenhum desses autores me parece negar a necessidade de uma eficácia simbólica da representação do poder, afinal, e é justamente nesse sentido que se opera o caráter mítico do texto constitucional. Lembremos que há quem defenda que o campo da política seria uma das atividades humanas mais imunes aos processos racionais $^{43}$.

Fábio Nadal oferece uma visão nesse sentido:

Entendemos que a legitimidade de uma Constituição se baseie em um mito, vale dizer, em uma crença ou em um conjunto de crenças (base irracional - a "fé na constituição") que propicia(m) o urdimento do sistema normativo (base racional), de acordo com um discurso competente (ideológico) com a finalidade (telos) de alcançar e manter a funcionalidade (simbólica, dominação, regulação integração). A Constituição, de qualquer modo, é, na síntese feliz de Marilena Chauí, “a morada de Deus”. (NADAL, 2006, P.21)

Podemos partir dessa fértil formulação de Marilena Chauí recortada por Nadal e tentar explorá-la mais detidamente.

\subsection{Poder Constituinte e o Verbo}

Em que sentidos então que a legitimidade da Constituição funcionaria através de sentidos míticos? Para começar, sabemos que mitos são principalmente narrativas, enquanto a Constituição não é exatamente uma narrativa, no sentido de seu texto não estabelecer uma

\footnotetext{
43 "The collectivity of psychotherapeutic experience suggests that the areas of politics and religion are for most of us deeply immune to the rational processes than are any other portions of our conscious beliefs and value systems. (Wahl, p.263 "The Relation Between primary and secondary identifications: Psychiatry and Group Sciences", in Eugene Burdick and Arthur J Brodbeck, American Voting Behavior (Glencoe, III, 1959) p.263. Apud: Edelman, 1964, p.19.
} 
sucessão de eventos lineares que realizem algo parecido com uma atualidade ou um enredo, com uma sequência mecânica de acontecimentos, mas ela certamente contém diversas narrativas, ou as sugere. Uma delas, como já foi proposto, sendo um mito etiológico, algo próximo de uma explicação simples e didática de como o Estado brasileiro veio a ser, uma narrativa que começa com uma declaração de intenções na primeira pessoa do plural e que procede numa série de assertivas no presente delimitando minuciosamente o ordenamento jurídico do Brasil.

É possível compreender essa delimitação sucessiva da ordem estatal como uma progressão temporal da mesma forma que uma enunciação criadora de uma narrativa que encena o momento da criação do mundo (uma cosmogonia) ${ }^{44}$. Por mais que a ordem da Constituição Federal não sugira exatamente uma progressão temporal, a sua ordenação sequencial permite esse eco interpretativo.

O preâmbulo da Constituição tem essa função então de instalar essa instância retórica formidável e tão peculiar configurada por um poder constituinte. Ele deixa claro seu status legítimo de representante do povo brasileiro e suas intenções de fundar um estado democrático, pacífico e justo $^{45}$.

\begin{abstract}
Nós, representantes do povo brasileiro, reunidos em Assembléia Nacional Constituinte, para instituir um Estado Democrático, destinado a assegurar o exercício dos direitos sociais e individuais, a liberdade, a segurança, o bem-estar, o desenvolvimento, a igualdade e a justiça como valores supremos de uma sociedade fraterna, pluralista e sem preconceitos, fundada na harmonia social e comprometida, na ordem interna e internacional, com a solução pacífica das controvérsias, promulgamos, sob a proteção de Deus, a seguinte Constituição da República Federativa do Brasil".
\end{abstract}

A Constituição, ou, melhor ainda, o Poder Constituinte então é uma voz que cria o Estado. A partir de sua enunciação (ou promulgação, no vocabulário mais técnico), o Estado brasileiro se vê constituído, ele passa a existir e ter legitimidade política para todos os fins práticos.

Claro que essa enunciação (ou promulgação) não é propriamente mágica, claro que ela só vem a existir e operar de maneira efetiva por causa de toda uma estrutura política que criou as

\footnotetext{
${ }^{44}$ Para uma interpretação semelhante, sugiro a interessantíssima análise logológica realizada por Kenneth Burke dos três primeiros capítulos do Gênesis e da relação que ele traça entre a criação do mundo enunciada no texto e a instalação de uma ordem política. The Rhetoric of Religion: Studies in Logology. Beacon Press, Boston. 1961.

${ }^{45}$ Frequentemente se comenta a temeridade de se invocar "a proteção de Deus" no preâmbulo da Constituição. De fato não é apropriado para a constituição de um estado laico. Mas os ecos míticos que aponto não dependem dessa invocação.
} 
condições enunciativas de sua legitimidade e efetividade prática. Um poder constituinte não pode efetivamente instalar sua instância retórica sem as condições políticas que o garantam. Daí a recorrente sugestão de que o poder constituinte seria um poder invocado ou conclamado por um momento político. A Constituição de 1988 foi antecedida de diversas práticas políticas e circunstâncias preparatórias. A instauração da Assembleia Nacional Constituinte da sua forma descentralizada, "de baixo pra cima" e aberta para a imprensa e sociedade civil foi possibilitada por movimentações sociais amplas que podem ser remontadas até pelo menos a década anterior da Constituinte em si. (PAIXÃO, 2011, p.163)

Mas é nessa capacidade politicamente construída da palavra constitucional de enunciar uma realidade que encontramos equivalências curiosas com estruturas míticas. Somos lembrados por Kenneth Burke que a palavra é o agente divino de criação em várias cosmogonias (como a cristã, a babilônica, a egípcia e a indiana ${ }^{46}$ ). E, como aponta Cassirer:

\footnotetext{
Este vínculo originário entre a consciência linguística e a mítico-religiosa expressa-se, sobretudo, no fato de que todas as formações verbais aparecem outrossim como entidades místicas, providas de determinados poderes míticos, e de que a Palavra se converte numa espécie de arquipotência, onde radica todo o ser e todo acontecer. Em todas as cosmogonias míticas, por mais longe que remontemos em sua história, sempre volvemos a deparar com esta posição suprema da palavra. (CASSIRER, 2006, p.64).
}

O Poder Constituinte não poderia ser considerado equivalente a essa arquipotência? A Constituição não seria o lugar onde radica todo o ser do Estado e todo o acontecer do Estado, ao ser invocada cotidianamente para fundamentar atos do Poder Público e decisões do Poder Judiciário? Somos lembrados da sugestão de Marilena Chauí de que a Constituição se tornou a nova morada de Deus ${ }^{47}$.

Lembremos a tendência histórica de manuais de Direito Constitucional de definir o poder constituinte como um poder pré-jurídico, ou um poder que meramente se apresenta, um poder incondicionado, autônomo, inicial e iniciador. O poder constituinte chega a lembrar bastante a causa sem causa ou o criador incriado da metafísica aristotélica ${ }^{48}$. E ainda que a tentativa de defini-lo em contraponto com outros poderes constitucionais por sua falta de condicionantes é

\footnotetext{
${ }^{46}$ BURKE, 1961. p.11

${ }^{47}$ NADAL, 2006, p.21)

${ }^{48}$ ARISTÓTELES, 2006, p.303.
} 
essencialmente a mesmo procedimento apofático usado em diversas tradições religiosas para tentar definir seu (no caso dos cristãos, a via negativa).

\subsection{Legitimidade e representação}

Para que a Constituição tenha efetividade dentro de um sistema de ramificações tão vastas numa sociedade tão complexa, é necessário que seu poder seja unívoco e absoluto. Seria impossível imaginar que o Estado tivesse seu poder de coação soberano questionado a toda hora, e que a positividade da ordem jurídica fosse posta em questão de maneira constante e precisasse efetivar seu domínio e demonstrá-lo em suas várias instâncias. Por isso, poder depende sempre de representação: Le pouvoir, c'est montrer ces signes, afin de faire croire naturellement et sans violence à la force (la violence) qu'ils represent. (MARIN, 2005, p.74)

Além da necessidade óbvia de representação, o poder ainda precisa de um aparato de justificação que não se apoia meramente em construções teóricas racionais, como propõe Balandier:

O poder exposto debaixo da iluminação exclusiva da razão teria pouca credibilidade. Ele não consegue manter-se nem pelo domínio brutal e nem pela justificação racional. Ele só se realiza e se conserva pela transposição, pela produção de imagens, pela manipulação de símbolos e sua organização em um quadro cerimonial. Estas operações se efetuam de modos variáveis, combináveis, de apresentação da sociedade e da legitimação das posições do governo. (...) A hierarquia é sagrada - como diz a etimologia - e o soberano depende da ordem divina, dela fazendo parte ou recebendo o seu mandato. Logo o passado coletivo, elaborado em uma tradição, em costume, é a ordem da legitimação. É uma reserva de imagens, de símbolos, de modelos de ação; permite empregar uma história idealizada, construída e reconstruída segundo as necessidades, a serviço do poder presente. Este gere e assegura seus privilégios colocando em cena uma herança. (BALANDIER, 1980, p.7)

Portanto, a complexa e multifacetada operação de estabilidade constitucional depende, entre outras coisas, de uma eficácia simbólica, como aponta Bourdieu (com o perdão de mais uma citação tão extensa): 
A política é o lugar, por excelência, da eficácia simbólica, ação que se exerce por sinais capazes de produzir coisas sociais e, sobretudo, grupos. Pelo poder do mais antigo dos efeitos metafísicos ligados à existência de um simbolismo, a saber, aquele que ser permite que se tenha por existente tudo o que pode ser significado (Deus ou o não-ser), a representação política produz e reproduz a cada instante uma forma derivada do argumento do rei calvo de França, que é caro aos lógicos: todo o enunciado predicativo que tenha como sujeito a "classe operária", qualquer que ele seja, dissimula um enunciado existencial (há uma classe operária). De modo mais geral, todos os enunciados que têm como sujeito um coletivo, Povo, Classe, Universidade, Escola, Estado, supõem resolvido o problema da existência do grupo em questão e encobrem esta espécie de "falsificação de escrita metafisica" que foi possível denunciar no argumento ontológico. O porta-voz é aquele que, ao falar de um grupo, ao falar em lugar de um grupo, põe, subrepticiamente, a existência do grupo em questão, institui este grupo, pela operação de magia que é inerente a todo o acto de nomeação. É por isso que é preciso proceder a uma crítica da razão política, intrinsecamente dada a abusos de linguagem que são abusos de poder, se se quer pôr a questão pela qual toda a sociologia deveria começar, a saber, a da existência e do modo de existência dos coletivos. (BOURDIEU, 1989, p.159)

Transportando o que diz Bourdieu para o poder constitucional, podemos apontar que legitimidade e a representatividade democrática do poder constituinte já é pressuposta na enunciação da Constituição, no ato ocorrido no preâmbulo da Constituição onde o poder constituinte nomeia a si mesmo e designa a si mesmo o poder de criar um Estado ${ }^{49}$. Em parte essa presunção se torna possível pelo caráter simbólico e mítico da enunciação, da linguagem que ela toma. A noção de representação não é distante da noção de crença, afinal de contas, como propõe Marin:

La notion de representation et celle de croyance sont ainsi très proches. La representation, dans et par les signes, represente la force. Des lors on aperçoit que les signes ne sont pas simplement des representants de forces saisissables seulement dans leurs effets, dans les effets qui les represent. Les representations sont des delegations de forces dans les signes. Elles sont ellles-memes des forces reflechies, des signes-effects qui sont ainsi eux-memes des forces.(MARIN, 2005, p.75)

Para Derrida (evocando Pascal e Montaigne), o fundamento final de toda autoridade seria sempre um fundamento místico, e não racional. Ele encontra uma arbitrariedade derradeira no

\footnotetext{
${ }^{49}$ No texto Declarations of Independence Derrida faz uma análise da declaração de independência e da Constituição dos Estados Unidos, investigando como se opera linguisticamente a representatividade da frase "We the people", por exemplo.
} 
ato fundador do direito e do estado, um ato que se confunde em diversos casos com a promulgação de uma constituição:

Le surgissement même de la justice et du droit, le moment instituteur, fondateur et justificateur du droit implique une force performative, c'est-à-dire toujours une force interpretative et un appel à la croyance (DERRIDA, 2005, p.32)

Tanto Derrida quando Lyotard encontram nos atos políticos e documentos textuais fundadores dos Estados Unidos (tanto a declaração de independência quanto a constituição americana) uma confusão da função performativa da linguagem com a função constativa ${ }^{50}$. Um ato de fala performativo não estabelece um fato, não faz uma assertiva que pode ser considerada verdadeira ou falsa (como acontece na função constativa da linguagem). Ao invés disso, ele realiza um ato. É o caso de alguém falar 'eu aposto em x', ou 'eu nomeio essa criança x'. A declaração de independência e a constituição americanas tratam a sua função performativa como se constativa fosse, ela instaura e 'performa' a coletividade que ela acredita estar simplesmente representando ou referenciando.

Além disso,

"Derrida sees revolutionary acts of foundation as concealing their own arbitrariness, their own lack of foundations by false hypostatization; Lyotard maintains that revolutionary acts of foundation hide the differend, that is the moment of spontaneity and creativity when the "gap", the "hiatus" in language is bridged. (BENHABIB, 1994, p.8)

As representações são delegações de forças que se tornam forças elas mesmas. No caso da Constituição, a palavra delegada pelo poder constituinte se vê numa quadrúpla representação (é a representação escrita de uma vontade política coletivamente representada por representantes de um povo coletivamente compreendido). A legitimidade desse complexo de representações poderia ser infinitamente questionada e minada por procedimentos críticos e cínicos de toda sorte. Em parte, isso não acontece (ou não acontece de uma maneira politicamente tão relevante)

\footnotetext{
${ }^{50} \mathrm{O}$ conceito é estabelecido em AUSTIN, John Langshaw. How to do things with words. 2. ed. Cambridge: Harvard Univ Press
} 
pela eficácia simbólica histórica e antropologicamente confirmada da palavra de instaurar uma ordem:

Nos relatos da Criação de quase todas as grandes religiões culturais, a Palavra aparece sempre unida ao mais alto Deus criador, quer se apresente como o instrumento utilizado por ele, quer diretamente como o fundamento primário de onde ele próprio, assim como toda existência e toda ordem de existência provém. (CASSIRER, 2006, 65)

Equacionando "ordem de existência” com uma ordem jurídica específica, podemos notar a curiosa equivalência do fenômeno constituinte com a descrição feita por Cassirer. A palavra do poder Constituinte, dotado de sua potência agonística e mítica de representatividade popular, é ao mesmo tempo o instrumento de efetivação desse Poder e o fundamento de toda sua instrumentalização posterior, o fundamento de toda a existência do poder estatal e da ordem jurídica a partir do momento que o poder Constituinte se cristaliza em poder estatal constituído.

\subsection{Deus Otiosus e o fim do mundo}

Eliade descreve a tendência de várias culturas míticas de compreender o Ente Supremo como retirado do mundo natural e dos humanos depois de realizar o seu trabalho inicial de criação, delegando a manutenção e ordenação do mundo a alguma segunda ordem divina ${ }^{51}$. Esse deus perde a sua atualidade religiosa ${ }^{52}$, segundo Eliade, tornando-se deus otiosus.

Traçando um paralelo com a Constituição, nós temos o poder constituinte originário e onipotente que se retira da ordem jurídica, gasto ou desativado, deus otiosus, e delega ao poder constituinte derivado ou às demais estruturas jurídicas por ele criadas (deuses fecundadores ou epifânicos de forças geradoras ${ }^{53}$ ) a manutenção da ordem por ele estabelecida.

Existe ainda a noção em algumas dessas culturas de que pode-se recorrer ao deus otiosus onipotente mais uma vez em casos de extrema necessidade. Da mesma forma, o poder constituinte igualmente pode ser reativado se a ordem política e jurídica se encontrarem num

\footnotetext{
${ }^{51}$ Seria o caso dos Yorubás, cujo 'proprietário do céu' Olorum teria abandonado o mundo e deixado um deus inferior, Obatala, cuidando de tudo. ELIADE, 2007, p.122.

${ }^{52}$ ELIADE, 2007, p.123.

${ }^{53}$ ELIADE, 2007, p.123.
} 
estado de extrema incompatibilidade com a vontade popular e com sua legitimidade institucionalmente constituída.

\begin{abstract}
O poder constituinte só é exercitado em ocasiões excepcionais. Mutações constitucionais muito profundas marcadas por convulsões sociais, crise econômicas ou políticas muito graves, ou mesmo por ocasião da formação originária de um Estado, não são absorvíveis pela esfera jurídica vigente. Nesses momentos, (...) a imprestabilidade das normas constitucionais vigentes para manter a situação sob a sua regulação fazem eclodir ou emergir este Poder Constituinte, que, do estado de virtualidade ou latência, passa a um momento de operacionalização do qual surgirão as novas normas constitucionais. (BASTOS, 2002, p.27).
\end{abstract}

$\mathrm{Na}$ verdade, podemos traçar ainda outro paralelo entre a consideração tradicional de que o poder constituinte é uma força onipotente que instaura o estado apenas para ser desativado, podendo ser conclamado novamente e retirado de sua latência se o estado por ele instituído se dissolver ou se desintegrar. É a tendência encontrada em diversos mitos do Fim do Mundo que Eliade descreve:

\footnotetext{
“Impliquant plus ou moins clairement la re-création d'um Univers nouveau, expriment la même idée archaique, et extremement répandue, de la "dégradation" progressive du Cosmos, nécessitant as destruction et as re-création périodiques." (ELIADE, 2007, 81)
}

O 'cosmos' jurídico ou político está todo tempo sujeito à degradação, por isso sempre pende sobre a ordem jurídica esse ligeiro milenarismo que aponta que o mundo pode ser destruído e recriado a partir do zero. Muitas tradições democráticas (incluindo a nossa) convivem com movimentos eventuais ${ }^{54}$ e de pequena expressão que propõem a instauração de um novo poder constituinte, acreditando que o fim da ordem atual e a recriação de uma nova serão necessariamente um movimento na direção de uma restauração de um estado ideal.

\footnotetext{
${ }^{54}$ Podemos destacar no Brasil o movimento recente do PSD de conclamar uma nova constituinte para 2014, assim como do PT em 2007 para fazer o mesmo e extinguir o Senado. Cada proposta tem suas particularidades, mas todas tem em comum a vontade de recomeçar o Estado.
} 


\section{Conclusão}

\section{A dimensão mítica como hipertrofia simbólica ou manejo ideológico}

Não é fácil extrair dessas aproximações conceituais, parentescos fugidios e ecos linguísticos uma série concatenada e encaixada de conclusões evidentes. O próprio tema escolhido reserva imediatamente sua porção de perplexidades acadêmicas aparentemente inesgotáveis, e de foro bastante técnico bastante alheio ao meu escopo. Comecemos então com uma via negativa, por aquilo que não quero dizer.

Primeiro, é bom esclarecer que eu não acho que a Constituição seja um mito. Não acho que podemos apontar uma única narrativa razoavelmente fixa encenada pelo texto constitucional ou por suas interpretações mais tradicionais. Espero que isso tenha ficado claro. O que temos infiltrado na nossa Constituição assim como nas compreensões teóricas que se fazem dela são categorias míticas e procedimentos narrativos míticos diversos, e não uma única forma narrativa inteiriça e destacável.

Procurando trabalhos aparentados da minha intenção, encontrei os livros de Marcelo Neves e Paulo Nadal, que fazem análises, respectivamente, dos aspectos simbólicos e míticos da constituição. Embora este trabalho coincida com os deles no sentido de tentar analisar o texto constitucional como um texto contendo forças significativas diversas das estritamente jurídicas, as análises diferem de maneira fundamental.

Neves (no seu livro A Constitucionalização Simbólica) explora uma visão da Constituição enquanto força simbólica bastante diversa da encenada aqui. Para ele, existiria uma hipertrofia da dimensão simbólica da Constituição. Uma hipertrofia caracterizada por uma incongruência avassaladora entre o programa de democracia material contido no texto constitucional e a sua concretização pelas instituições do Estado brasileiro. Essa incongruência significaria não só que se vê fundamentalmente comprometida a pretensão do Estado Brasileiro de se constituir como um Estado democrático de direito pleno, mas que se veria comprometida até a capacidade do texto constitucional de gerar as funções e as estruturas necessárias para uma vivência constitucional mínima, já que não se criariam expectativas normativas congruentemente generalizadas, de forma que até mesmo a autorreflexividade consistente necessária para a manutenção do sistema jurídico inexistiria.

Ou seja, seguindo a terminologia e a construção teórica de Luhmann, a constitucionalização simbólica (que, segundo Neves, opera-se claramente no Brasil) implicaria 
problemas sérios na capacidade de reprodução do direito, de forma a descaracterizá-lo enquanto sistema autopoiético $^{55}$. Ao invés, teríamos aqui e em outros países de modernidade periférica um processo de alopoiese, com a sobreposição de outros códigos de comunicação no sistema jurídico, especialmente do econômico e do político. Isso afetaria a autonomia operacional do sistema jurídico de maneira decisiva. ${ }^{56}$

Esse caráter hipertroficamente simbólico da linguagem constitucional se manifestaria de maneira particularmente marcante nas chamadas "normas programáticas de fins sociais" 57 . A constitucionalização simbólica teria principalmente uma função de imunizar o sistema político contra a possibilidade de alternativas políticas substanciais, transferindo a solução dos problemas gravíssimos dos subintegrados para um futuro remoto ${ }^{58}$.

Ao tentar explicitar a dimensão simbólica e mítica da Constituição (dimensões que não se confundem, mas que essencialmente se entrelaçam), não estou almejando uma construção semelhante à de Neves. Apesar da conotação predominantemente negativa que as qualidades 'míticas' e 'simbólicas' podem carregar a princípio, falando de um texto cujo sentido de ser é eminentemente pragmático e político, com uma pretensão de efetividade e instrumentalidade num sem-número de situações fáticas cruciais, a minha abordagem pretende elucidar principalmente a maneira com a qual a Constituição toma emprestados aspectos dessas correntes pouco jurídicas de significado no ato fundador do Estado e na legitimação sistemática irradiada pelo texto constitucional em todos os subsistemas jurídicos e instâncias de efetividade.

Ou seja, minha preocupação é principalmente com a Constituição enquanto metalinguagem jurídica ou instância reflexiva, na capacidade que a Constituição tem de não só legitimar um momento e uma representação específica do Estado, mas de manter essa legitimidade nas sucessivas e contínuas atualizações e realizações constitucionais cotidianas necessárias para a efetivação de uma democracia material. Significaria adotar um escopo excessivo analisar a fundo de que maneira essa linguagem efetivamente age nas várias instâncias operativas de aplicação do Direito, passando pelo âmbito legislativo, executivo e as várias instâncias do judiciário, mas imagino que uma análise nesse sentido seria, sim, possível.

\footnotetext{
${ }^{55}$ NEVES, 2011, p.154

${ }^{56}$ NEVES, 2011, p.146

${ }^{57}$ NEVES, 2011, p. 115

${ }^{58}$ NEVES, 2011, p.101.
} 
O próprio Neves reconhece, amparado por Burdeau e Edelman, que as Constituições que ele denomina efetivamente 'normativas' (seria o caso da Constituição dos Estados Unidos, por exemplo) desempenham também função simbólica. Existiria nesses casos uma interação saudável entre o simbólico e o instrumental e a Constituição funcionaria de fato "como instância reflexiva de um sistema jurídico vigente e eficaz." (NEVES, 2011, p.96)

Minha análise considera efetivamente a Constituição brasileira uma constituição normativa, ainda que uma constituição normativa modus in rebus (se é que isso é possível). De fato, é gritante e óbvia a incongruência entre os direitos fundamentais criados pela Constituição de 1988 e a realização Constitucional do Estado Brasileiro, não é a toa que o debate em torno da efetividade dos Direitos fundamentais é talvez hoje o debate mais premente do Constitucionalismo Brasileiro ${ }^{59}$. Não resta dúvida de que a análise dessa incongruência entre a norma e a realidade e todos os desafios enfrentados pela efetivação dos Direitos Fundamentais precisa ser feita, e que o livro do professor Neves significa uma perspectiva bastante fértil nesse sentido. Mas não me parece, sem entrar em méritos estatísticos ou quantitativos, que a incongruência entre a expectativa normativa gerada pelas normas da Constituição e a concretização do estado brasileiro chegue a comprometer a autonomia operacional do sistema jurídico e minar a capacidade do texto constitucional de servir de instância reflexiva para um sistema jurídico vigente. Ao que entendo, nada impede que as localizadas insuficiências grosseiras e grotescas do nosso estado convivam com suas várias generalizadas instâncias de eficácia. Também se pode fazer objeções à demarcação tão direta de algumas culturas constitucionais serem plenamente normativas enquanto algumas outras (de modernidade periférica) não conseguirem nem instituir sistemas jurídicos plenos.

Existem de fato setores específicos de ineficácia grosseira do Estado brasileiro onde a vigência de um sistema jurídico saudável e pode e deve ser questionada (a condição sub-humana da população carcerária brasileira é uma delas, por exemplo), mas essas violentas incongruências não impedem que em diversos âmbitos o texto constitucional efetivamente tenha uma vigência sistêmica ampla e significativa. Talvez seja o caso de simplesmente compreender que instituições políticas são sempre atualizações bastante defeituosas e acidentadas de ideais teóricos construídos sobre generalizações abstratas. Corsi aponta sobre os valores constitucionalmente garantidos que estes "têm sentido, apenas, se é possível que (...) sejam

\footnotetext{
${ }^{59}$ BARROSO, Luís Roberto. Direito Constitucional e a Efetividade de suas normas. Renovar, Rio de janeiro, 2009.

${ }^{60}$ BARCELLOS, Ana Paula. A Eficácia Jurídica dos Princípios Constitucionais: A dignidade da pessoa humana. Renovar, Rio de Janeiro, 2008.
} 
especificados num contexto organizado, para sermos precisos, no interior de procedimentos." (CORSI, 2001, p.8) Por isso, o esforço tanto político quanto jurídico deve ser de encontrar as formas de interpretação e operação do direito que tornem a comunicação entre a sociedade, o Estado e os valores constitucionais mais efetiva e instrumental, cristalizada em procedimentos, estabelecendo uma gramática de práticas e usos do texto constitucional ${ }^{61}$.

A pretensão de destacar a corrente mítica subterrânea do texto constitucional não é então a de evidenciar uma hipertrofia simbólica e a falta de conexão entre a realidade institucional brasileira e um mito vazio cometido pelo texto constitucional e suas realizações. Nem seria semelhante à de Fábio Nadal, que chama a Constituição de "quimérica" por sua constituição mítica e ilógica, condensadora de valores antagônicos ${ }^{62}$, e aponta a falta de relação entre os valores contidos na constituição de um país e sua efetiva cultura democrática ${ }^{63}$.

Não uso 'mito' e suas sinonímias e termos correlatos de maneira predominantemente negativa. Ao invés disso, não seria possível que as equivalências encontradas entre a nossa Constituição e categorias míticas sejam apenas mais uma maneira de se explicar a viabilidade institucional e prática desse que é talvez o instrumento político mais importante da modernidade? A Constituição moderna não apenas sobreviveu ao longo século $\mathrm{XX}$, mas parece até ter se fortalecido com todos os questionamentos suscitados em torno dos regimes totalitários que sulcaram a memória recente, assim como com os progressivos debates envolvendo novas concepções de racionalidade democrática.

No Brasil, que é logicamente o caso que mais nos toca, tivemos um importante momento de redemocratização marcado pelo ímpeto constitucionalista, uma efetiva movimentação social que culminou numa Assembleia Constituinte descentralizada e bem pouco controlável ${ }^{64}$, plural e aberta, que resultou num documento político maduro e progressista. Ainda que as garantias prolixas da nossa Constituição discordem flagrantemente da realidade do nosso Estado (fato que parece indiscutível), existem esforços teóricos e institucionais no sentido de efetivar e aplicar a utopia proposta nos lineamentos constitucionais.

Em vários dos aspectos multifacetados oferecidos por um documento tão importante e rico quanto é a Constituição acredito que podemos enxergar esses ecos míticos. No seu ato

\footnotetext{
${ }^{61}$ PAIXÃO, CARVALHO NETTO, 2007, p.12

${ }^{62}$ NADAL, 2006, p.124

${ }^{63}$ NADAL, 2006, p.102

${ }^{64}$ PAIXÃO, 2011,p.164
} 
fundante do Estado, nos ritos que atualizam e aplicam no caso concreto, na legitimidade política continuamente sustentada e na constante utopia que ela impõe como horizonte dos aplicadores e intérpretes do direito.

Já argumentei que talvez a força simbólica da Constituição se reforce desses elementos míticos estruturais para endurecer sua vigência e efetividade dentro de um vasto sistema normativo e institucional, mas qual seria a explicação desse fenômeno? Penso que podemos desconsiderar a possibilidade (aparentemente pouco plausível) de que os operadores do direito e os sucessivos construtores históricos das ferramentas constitucionais tenham se servido de maneira inteiramente deliberada e ardilosa dessas semelhanças linguísticas e simbólicas ao construir o edifício teórico constitucional. Como sugere Edelman ao discorrer sobre os usos simbólicos da política:

There is no implication here that elites consciously mold political myths and rituals to serve their ends. Attempts at such manipulations usually become known for what they are and fail. What we find is social role taking, not deception. Potent condensation symbols, as already noted, are created through living "within the social texture"; this is notably true of political forms which become symbols." (EDELMAN, 1964, p.20)

Para esboçar uma resposta, precisamos invocar a já-comentada equivalência entre o logos e o mythos defendida por alguns autores, assim como a porosidade entre as categorias míticas e conceituais do pensamento. Nesse enfoque, podemos nos reportar ao Derrida que coloca a metafísica e a razão como a mitologia branca $^{65}$ do homem europeu, a mitologia que apaga os seus vestígios metafóricos e naturaliza a sua gênese histórica, que transforma figuras de linguagem sucessivas em predicações de identidade, transforma semelhanças casuais nas bases para ontologias naturais. A atividade jurídica não seria diferente das demais empreitadas racionais modernas, sendo igualmente uma atividade de produção de sentido mediada por esses conceitos hipostasiados e naturalizados. E a Constituição seria talvez o momento mais forte dessa hipostasia naturalizada que Derrida reconhece como uma constante na racionalidade logocêntrica, já que o texto constitucional é a instância legal que precisa necessariamente

\footnotetext{
${ }^{65}$ DERRIDA, Jacques. White Mythology. Metaphor in the Text of Philosophy. New LiteraryHistory,Vol.6, No.1, On Metaphor. (Autumn, 1974), pp. 5-74. F. C. T. Moore
} 
recorrer a uma esfera extrajurídica para garantir o seu caráter absoluto. Como na metáfora que Derrida destrincha ao longo do texto (introduzida por Platão e repetida de forma variada ao longo do pensamento ocidental), do pensamento e do esclarecimento como um sol que ilumina o mundo, tornando-o inteligível em todos seus elementos, irradiando sua energia quase como uma força constitutiva. Podemos encontrar ecos dessa metáfora mítica do pensamento na concepção da constituição como uma fonte irradiante de positividade jurídica., o "sol" que ilumina e torna inteligível e vigente o sistema jurídico.

Para um pensador como Kolakowski, especialmente preocupado com a presença duradoura do mito no pensamento contemporâneo, essa tendência é ainda mais abrangente:

Thus, all reasons in which the mythical consciousness is rooted, both in is initial variant, and in its metaphysical extensions, are acts affirming values. They can be fruitful to the extent that they satisfy the real need for controlling the world of experience by a meaning-giving interpretation of it, referring it to unconditioned Being. (KOLAKOWSKI, 2002, p.5)

Não é isso que faz a Constituição? Ela refere todo ordenamento jurídico a um Ser incondicionado de validação interna, com a finalidade instrumental de significar eventos no mundo de acordo com uma operação binária de sentido e, dessa forma, ter meios de controlar uma realidade externa.

A Constituição pode ainda ser considerada um God-term, no sentido proposto por Kenneth Burke:

In any term we can posit a world, in the sense that we can treat the world in terms of it, seeing all as emanations, near or far, of its light. Such reduction to a simplicity being technically reduction to a summarizing title or "God term" (Burke, 105)

Tudo que se inclui dentro do sistema jurídico precisa ser visto de acordo com a Constituição, como recebido ou não em seu seio, como uma confirmação ou instância positiva de suas normas ou como uma distorção que precisa ser considerada juridicamente inexistente. Aquilo que é inconstitucional não existe, não é aceito dentro da ordem estabelecida. 
"Constitution as word for substance or ground which imposes the quality of its motivation upon all acts enacted within its circumference (the circumference, in such cases being considered coextensive with the span of time in which the Constitution is accepted as the law of the land)" (BURKE, 376)

Uma outra maneira de dizê-lo seria de que a sociedade constrói uma ficção necessária com a Constituição. Não que a Constituição seja fictícia no sentido de sua representação política ser falsa, ou de seu conteúdo programático ser incompatível com a realidade (embora ele até seja, no caso do Brasil, como já admiti). Ela pode ser considerada fictícia no sentido de que toda abstração altamente convencional pode ser considerada fictícia, no sentido de que ela contém um conteúdo arbitrário e historicamente contingente que, no entanto, precisa colocar a si mesmo como uma forma absolutamente positiva para ser material e institucionalmente viável. O movimento intelectual não é dessemelhante àquele realizado no poema de Wallace Stevens "Notes toward a Supreme Fiction",66, onde ele propõe de maneira triunfante e convicta a crença derradeira e deliberada numa ficção que se sabe que é uma ficção.

Para Hazard Adams, toda ficção cultural teria origem comum na forma simbólica do mito ${ }^{67}$. Uma das manifestações do poder mítico de significação seria a sua versão simbólica secular, que compreende inteiramente o poder radicalmente constitutivo da linguagem, que tem perfeita consciência que o que ocorre nessa geração mítica é um ato particular de criação em direção a uma recepção cultural ${ }^{68}$.

Essa concepção não é dessemelhante da ideia de Cassirer que toda linguagem simbólica, incluindo a jurídica, provém de uma mesma origem no campo mítico. ${ }^{69}$

\section{O mito político totalitário}

Muitos enxergaram no totalitarismo assassino do século XX uma poderosa e terrível instância do poder político mítico. Mesmo um pensador como Ernst Cassirer, que possuía uma sofisticada compreensão da imaginação mítica e da sua relação com a força constitutiva da linguagem, enxergava na relação entre o mito e a política uma tendência inevitável para o estado totalitário e a barbárie.

\footnotetext{
${ }^{66}$ STEVENS, Wallace. The Collected Poems. New york: Alfred A. Knopf, 1961, p.380

${ }^{67}$ VON HEMDY, 2001. p.334

${ }^{68}$ ADAMS, 1983. Apud:: VON HEMDY, Op.Cit, p.334

${ }^{69}$ HABERMAS, Jurgen. The Liberating Power of Symbols. The MIT Press, 2001.p.20.
} 
Cassirer parece enxergar a potência mítica na política apenas em conexão à narrativas envolvendo figuras carismáticas e raças predestinadas (remetendo a Carlyle), forças que vem à tona em momentos de crise de alguma sociedade, mesmo das modernas e racionais ${ }^{70}$. Renovando deliberadamente as possibilidades contidas em elementos rituais e em narrativas míticas arcaicas seria possível para uma figura carismática controlar a população e instalar um regime totalitário (o uso nazista de propaganda, de narrativas germânicas e de rituais coletivos meticulosamente coordenados é um fato já de conhecimento comum). Seria tarefa da filosofia compreender da melhor forma possível esse fenômeno do mito político moderno de forma a poder combatê-lo. $\mathrm{O}$ pensamento mítico seria uma força caótica a ser controlada pela filosofia, pela arte e pela civilização. $^{71}$

Adorno e Horkheimer também relacionam o mito político moderno ao totalitarismo na obra Dialética do Esclarecimento. É difícil delimitar de uma maneira simples e sintética o conceito de mito contido nesse livro. Os dois autores tentam destrinchar o conceito de esclarecimento ao longo da história ocidental, um conceito que pode ser compreendido como um procedimento racional de desencantamento do mundo, de erradicação das potências míticas da natureza e de instrumentalização de todos seus elementos (assim como da sociedade e do indivíduo). Mas embora o esclarecimento seja um esforço de desmitologização, ele na verdade já conteria uma força geradora mítica em si $^{72}$ (assim como o mito já conteria também o esclarecimento no seu núcleo, como fica claro na análise da Odisséia contida no livro).

Do mesmo modo que os mitos já levam a cabo o esclarecimento, assim também o esclarecimento fica cada vez mais enredado, a cada passo que dá, na mitologia. Todo conteúdo, ele o recebe dos mitos, para destruílos, e ao julgá-los, ele cai na órbita do mito. (ADORNO, HORKHEIMER, 1985, p.23)

O mito seria essa força do status quo, de um pensamento de identidade homogêneo, uma força política sempre tendente ao totalitarismo. Segundo Hemdy, o mito de Adorno e Horkheimer seria qualquer instituição cultural ou conceito hegemônico que se isenta de contingência histórica porque é colocado como parte de uma ordem eterna das coisas ${ }^{73}$.

\footnotetext{
${ }^{70}$ CASSIRER, 1946, p.280.

${ }^{71}$ CASSIRER, 1946, p.298.

${ }^{72}$ ADORNO, HORKHEIMER, 1985, p.23.

${ }^{73}$ VON HEMDY, 2001, p.295.
} 
Nessa compreensão do mito como um pensamento homogêneo de identidade e de uma instituição que tenta se isentar da contingência histórica acredito que podemos encontrar equivalências com a Constituição, respectivamente com a tentativa de instalar uma ordem ou sistema total e vigente e com a legitimidade auto-imposta do texto constitucional. Mas no meu entendimento, o caráter mítico que tento localizar na Constituição moderna se isenta integralmente das consequências totalitárias descritas tanto por Cassirer quanto por Adorno \& Horkheimer. A relação entre os sistemas totalitários do século XX e a força mítica de suas narrativas nacionais e figuras carismáticas é bastante evidente, e não deve ser banalizada. Mas me parece um erro confundir toda infiltração de pensamento mítico na política como uma tendência ao totalitarismo, uma força caótica e irracional a ser controlada ou um sistema fechado e sufocante de identidade.

É bem evidente que a Constituição moderna (e, em particular, a brasileira) de que estamos tratando contém no seu núcleo tanto a possibilidade de revisão democrática quanto a necessária manutenção da diferença e do pluralismo. A Constituição brasileira tem a garantia plena de direitos fundamentais instalada bem no seu centro. É uma pretensão a que o Estado precisa sempre almejar, uma medida abstrata sempre presente de suas instituições (ainda que em muitas instâncias ainda sofra para receber sua efetividade). Parece-me que o caráter mítico da constituição merece antes comparação com a força simbólica da utopia do que com os sistemas totalitários.

\section{A constituição como forma simbólico-mítica da democracia contemporânea}

A Constituição consegue realizar a tarefa quase impossível de reconciliar numa forma simbólica a ideia fundamentalmente aberta, instável e arriscada de democracia contemporânea com uma positividade estável e absoluta que não pode ser questionada ou relativizada.

Apesar de todas as construções teóricas que procuram fundamentar a legitimidade da Constituição e a racionalidade absoluta de sua forma, é difícil escapar do fato de que muito de sua eficácia parece se apoiar em imagens míticas. Para Kenneth Burke, a imagem mítica pode ser considerada retoricamente "as figuring a motive that transcends reason. It presumably represents man's relationship to an ultimate ground of motives not available for empirical inspection" (BURKE, 1962, p. 727) Por mais que a Constituição seja racionalmente justificável, a relação simbólica que 
muitos de seus operadores e intérpretes mantém com ela parece ser claramente mítica, como uma força derradeira indisponível ao questionamento humano. Talvez a Constituição moderna não teria se tornado este admirável paradigma de ordenamento político, legitimação democrática e instrumento de democracia material que ela se tornou (esta "improvável, imprevisível e surpreendentemente exitosa invenção da Modernidade", PAIXÃO, CARVALHO NETTO, 2007, P.102) se sua eficácia simbólica não fosse tão fortalecida por essas imagens míticas. Esse caráter mítico não deve ser considerado uma fraqueza ou uma inconsistência do projeto constitucional. Ricoeur defende que "the claim of the logos to rule over mythos is itself a mythical claim" (RICOEUR 1991, p. 486, apud: COUPE, 2009, p.88)

É bem claro que estamos bem longe dos ecos míticos do totalitarismo e da rigidez de algumas sociedades arcaicas. E diante da forma simbólica e mítica realizada pela Constituição, o mais oportuno não é efetivamente perguntar se a forma é verdadeira, se é plenamente consistente dentro de uma argumentação teórica, se seus pressupostos políticos são passíveis ou não de uma desconstrução. Se a filosofia do século XX nos ensinou alguma coisa, é que praticamente todo artefato cultural e linguístico pode ser desmontado como uma construção arbitrária ou uma instância de um falogocentrismo ilegítimo. Por mais que essas desconstruções possam ter um papel histórico importante, parece ser mais importante ainda falar da efetividade democrática de um texto constitucional, e é justamente aí que o caráter mítico da constituição deve fazer sua contribuição. Lembremos que:

$[\mathrm{M}] \mathrm{yth}$ is neither true nor false in a theoretical sense but viable or not viable for the tasks (both theoretical and other wise) which confront us. This viability is not determined in intellectual terms but in the very process of living, by whether or not one is energized, whether or not problems are being solved, whether or not life is integrated at a variety of levels, whether or not it is endowed with a significance that pulls one toward the future in hope. Viability is not determined in advance of inhabiting a myth . . . 74

Depois da ocorrência terrível no século XX de mitos políticos fundando e legitimando uma rigidez totalitária, a sociedade contemporânea erigiu para si um mito político próprio. Um mito político aberto para a diferença e para a transformação social, para a utopia dirigente, uma ficção secular suprema e necessária.

\footnotetext{
${ }^{74}$ SCARBOROUGH, 1994 p. 110, apud: COUPE, 2009, p.85
} 
Confrontado com os desafios da legitimação política e a organização do poder público, a sociedade moderna cristalizou progressivamente uma estrutura política e jurídica que tornasse viável o paradigma do Estado democrático de direito. Para realizar essa tarefa os seus sucessivos e variados artesãos se serviram de algumas das ferramentas que sempre estiveram disponíveis para a imaginação humana, repetindo estruturas presentes em diversos outros âmbitos simbólicos e representações coletivas. Giambattista Vico acreditava que o deus Júpiter havia sido criado por homens diante de um céu trovejante, homens tentando nomear e entender aquele fenômeno tão vasto e terrível e intuindo com suas imaginações poéticas e faculdades linguísticas criadoras um vasto corpo animado ${ }^{75}$.

E agora diante de uma sociedade altamente complexa e plural, cujos valores positivos informadores construídos intersubjetivamente são principalmente de manutenção da diferença e da abertura democrática, o ser humano mais uma vez compreende um "vasto corpo animado", ainda que um admitidamente abstrato e fictício, inteiramente criado por textos e por suas interpretações e atualizações, a cristalização mítica de um poder democraticamente legítimo impossível de ser representado de uma maneira plena, impossível de ser fixado de uma maneira absoluta, um corpo de diretrizes normativas que permite não só a integração de uma estrutura estatal positiva e estável mas ainda um horizonte de efetivação de direitos fundamentais futuros.

\footnotetext{
${ }^{75}$ VICO, 1973, P.85. No original, “um gran corpo animato”, Sciencia Nuova, 1744, § 377.
} 


\section{Referências Bibliográficas}

ADORNO, Theodor HORKHEIMER, Max. Dialética do esclarecimento: fragmentos filosóficos. Zahar, 1985, Rio de Janeiro.

ARISTÓTELES, Metafísica, Bauru, EDIPRO, 2006.

AUSTIN, John Langshaw. How to do things with words. 2. ed. Cambridge: Harvard University Press

CANOTILHO, Direito Constitucional e teoria da constituição, Almedina, Coimbra, 1997

BALANDIER, George. O Poder em Cena. Editora UnB, 1980.

BARTHES, Roland. Mythologies. Editions du Seuil, Paris, 1957.

BARROSO, Luís Roberto. Direito Constitucional e a Efetividade de suas normas. Renovar, Rio de janeiro, 2009.

BARCELlos, Ana Paula. A Eficácia Jurídica dos Princípios Constitucionais: A dignidade da pessoa humana. Renovar, Rio de Janeiro, 2008

BASTOS, Celso Ribeiro. Curso de Direito Constitucional, São Paulo, Celso Bastos Editora, 2002.

BENHABIB, Seyla. Democracy and Difference: Reflections on the Metapolitics of Lyotard and Derrida. In: The Journal of Political Philosophy: Volume 2, Number I, 1994. p.1-23

BLUMENBERG, Hans. La Raison du mythe. Gallimard, 2005

BOTTICI, Chiara. The Philosophy of Political Myth. Cambridge University Press, 1999

BOURDIEU, Pierre. O Poder Simbólico. Bertrand Brasil, Rio de Janeiro, 1989

BURKE, Kenneth. The Rhetoric of Religion: Studies in Logology. Beacon Press, Boston. 1961. Language as symbolic action. Berkeley: Univ California Press, 1968 Grammar of motives and a rhetoric of motives(a). Cleveland: World Publishers, 1962. 
BURKE, Peter. Vico. São Paulo, Editora UNESP, 1997

CASSIRER, Ernst. Linguagem e Mito. Perspectiva, São Paulo, 2006

. The Myth of The State. Yale University Press, New Haven, 1946

CAZENEUVE, Jean. Sociologie du Rite. Presses Universitaires de France, 1971

CORSI, Giancarlo. Sociologia da Constituição. Trad. Juliana N. Magalhães. Revista da

Faculdade de Direito da Universidade Federal de Minas Gerais. №39. Belo Horizonte: UFMG, janeiro-junho de 2001.

COUPE, Lawrence. Myth, Routledge, London, 2009.

DERRIDA, Jacques. Force de loi. Éditions Galilée, Paris, 2005.

White Mytholoogy: Metaphor in the Text of Philosophy. New LiteraryHistory,Vol.6,

No.1, On Metaphor. (Autumn, 1974), pp. 5-74. F. C. T. Moore

EDELMAN, Symbolic uses of Politics. University of Illinois Press, Chicago, 1964.

ELIADE, Mircea. Aspects du Mythe. Gallimard, Paris, 2007.

FORTES, Luíz Roberto Salinas; NASCIMENTO, Milton Meira. A constituinte em debate:

Colóquio realizado de 12 a 16/05/86, por iniciativa do Depto. de Filosofia da USP. São Paulo:

Sofia, 1987

FRAZER, James. The Golden Bough. Wordsworth Classics, Kent, 1993.

FREUD, Sigmund. Totem e tabu. Rio de Janeiro: Imago, 2005

FRYE, Northrop. The Anatomy of Criticism. Princeton University Press, Princeton, 1957.

GARCÍA-PELAYO, Manuel. Derecho Constitucional Comparado. Alianza Editorial, Madrid, 2000

GOYARD-FABRE, Simone. Os princípios filosóficos do direito político moderno. São Paulo, Martins Fontes, 1999. 
GRAS, Vernon W. Myth and the Reconciliation of Opposites: Jung and Levi-Strauss. Journal of the History of Ideas ,Volume 42, Issue 3, 1981. p.471-488.

HABERMAS, Jurgen. Direito e democracia: entre facticidade e validade, volume II. Tradução: Flávio Beno Siebeneichler 2.ed. Tempo Brasileiro, Rio de Janeiro, 2003 ,Crise de Legitimação no capitalismo tardio. Tempo Brasileiro, Rio de Janeiro, 2002. ,The Liberating Power of Symbols. The MIT Press, 2001

KOLAKOWSKI, Leszek. The Presence of myth. Chicago: University of Chicago Press, 2002.

LÉVI-STRAUSS, Claude. Antropologia Estrutural. Tempo Brasileiro, Rio de Janeiro, 1985. , Myth and Meaning. Routledge. Digital Edition, 2009. ,Pensée sauvage. Paris: Plon, 1966

MALINOWSKI, Bronislaw. Magic, science, and religion: and other essays. London: Condor, 1974

MARIN, Louis. Politiques de la representacion. Editions Kimé. Paris. 2005

MENDES, Gilmar Ferreira, COELHO, Inocêncio Martires, BRANCO, Paulo Gustavo Gonet. Curso de Direito Constitucional. Saraiva, São Paulo, 2007.

NADAL, Fábio. A Constituição como mito: o mito como discurso legitimador da constituição. Método, São Paulo, 2006.

NEVES, Marcelo. A Constitucionalização Simbólica. Martins Fontes. São Paulo, 2011.

PAIXÃO, Cristiano. CARVALHO NETTO, Menelick de. Entre permanência e mudança: reflexões sobre o conceito de constituição. In: MOLINARO, Carlos Alberto; MILHORANZA, Mariângela Guerreiro; PORTO, Sérgio Gilberto. (Org.). Constituição, jurisdição e processo - estudos em homenagem aos 55 anos da Revista Jurídica. $1^{\text {a }}$ ed. Sapucaia do Sul, RS: Notadez, 2007, p. 97-109. . Modernidade, Tempo e Direito. Del Rey, 2002. 
, Direito, política, autoritarismo e democraciano Brasil: da Revolução de 30 à

promulgação da Constituição da República de 1988 Araucaria. Revista Iberoamericana de Filosofía, Política y Humanidades, año 13, nº 26. Segundo semestre de 2011. Pp. 146-169.

SEGAL, Robert A. Myth: a very short introduction.Oxford, Oxford University Press, 2004.

SILVA, José Afonso da. Curso de Direito Constitucional Positivo. São Paulo, Editora dos Tribunais, 1990.

STEVENS, Wallace. The Collected Poems. New york: Alfred A. Knopf, 1961

VICO, Giambattista. Princípios de uma ciência nova acerca da natureza comum das nações:

(acerca da natureza comum das nações). São Paulo: Abril Cultural, 1973.

VIVEIROS DE CASTRO, Eduardo. A Inconstância da Alma Selvagem e outros ensaios de antropologia. Cosac \& Naify, São Paulo, 2002.

VON HEMDY, Andrew, The modern construction of myth, Indiana University Press, 2001

WITTGENSTEIN, Ludwig. Investigações Filosóficas. Abril Cultural, São Paulo, 1984. 